\title{
INFORMATION PROVISION OF LOGISTICS SUPPORT IN CIVIL PROTECTION
}

\author{
Eva SVENTEKOVÁ ${ }^{1}, Z_{\text {deněk DVOŘÁK }}^{2}$ \\ ${ }^{1}$ Faculty of Special Engineering, University of Zilina, st. Majova 32, 01026 Zilina, Slovakia. Corresponding author. E- \\ mail: Eva.Sventekova@fsi.uniza.sk \\ ${ }^{2}$ Research Department of Crisis Management, Faculty of Special Engineering, University of Zilina, st. Majova 32, 010 \\ 26 Zilina, Slovakia
}

Accepted 15 October, 2011

\begin{abstract}
The paper describes new view for possible logistics support in civil protection. New information and communication technology have great possibility of using in all people activities. Civil protection is very specific field, where all proposal solutions bring results with very different probability.
\end{abstract}

Keywords: information provision, logistics support

\section{INTRODUCTION}

Nowadays, life is becoming more complex together with growing of population, developing of technology and increasing of risks. Hence, authorized people have to take more powerful measures to struggle against natural, weather and technology disasters. When disasters occur, it is vital to rescue the large number of people in the shortest period of time and provide essential needs with appropriate methods. But all these activities depend on having effective disaster management plans, good teams, sufficient equipments and correct practice knowledge. When we come across a kind of disaster, we have to be well prepared to implement our plans.

Nowadays, civil protection and its logistics support is a science in universities and it has a scientific worth, not a simple work. So, realizing of this process requires systematic effort to manage and reply it. Actually logistics and its support in civil protection is a broad topic, branch of science. We can say lots of things in point of plans, preparedness, regulations, implementations etc. for all kind of disasters and crises situations.

Logistics may be identified in various types of definition today but most of them have a common side to describe it generally. It can be defined as a process of planning, implementing, organizing and controlling the information and sources from point of origin to point of needs effectively, speedy and timely. Shortly, it means having the right thing, at the right place, at the right time. Thus, the most important part of this process arises as administration of it. If we want to be accomplished in this work, we have to provide some basic rules or principles about solving problems. So, we need accurate information sources and moves. So we don't win the race with wrong information.

\section{LOGISTICS SUPPORT IN CIVIL PROTECTION}

Logistics may be defined as the process of planning, implementing and controlling the efficient, effective flow and related information from point of origin to point of consumption (including inbound, outbound, internal and external movement) for the purpose of conforming to the customer's requirements. For logistics support in civil protection is most important to create concrete system. The specific properties of this system are intangible flows - services as health service, deliverance, displacement, accommodation, protection, information flow, etc. These services can be bound by using some material. Some possible structure of elements in logistics support system in crises situations solving is in figure 1 .

For logistics support of disasters, it is the best to divide it components to take care of disaster situation effectively. So, we can divide logistics in two parts, planning and implementation. 
First of all, planning is based on gathering correct information about current opportunities and sources. If plans are based on wrong data and information, they cannot be useful in practice, also they might cause crucial damages. Planning is an activity to evaluate by taking into account that which situation might we come across or what will we do in the future and to determine a form of movement. Plans provide us with:

- People and institutions gain time.

- Economic sources are not wasted.

- It provides to reach determined aim.

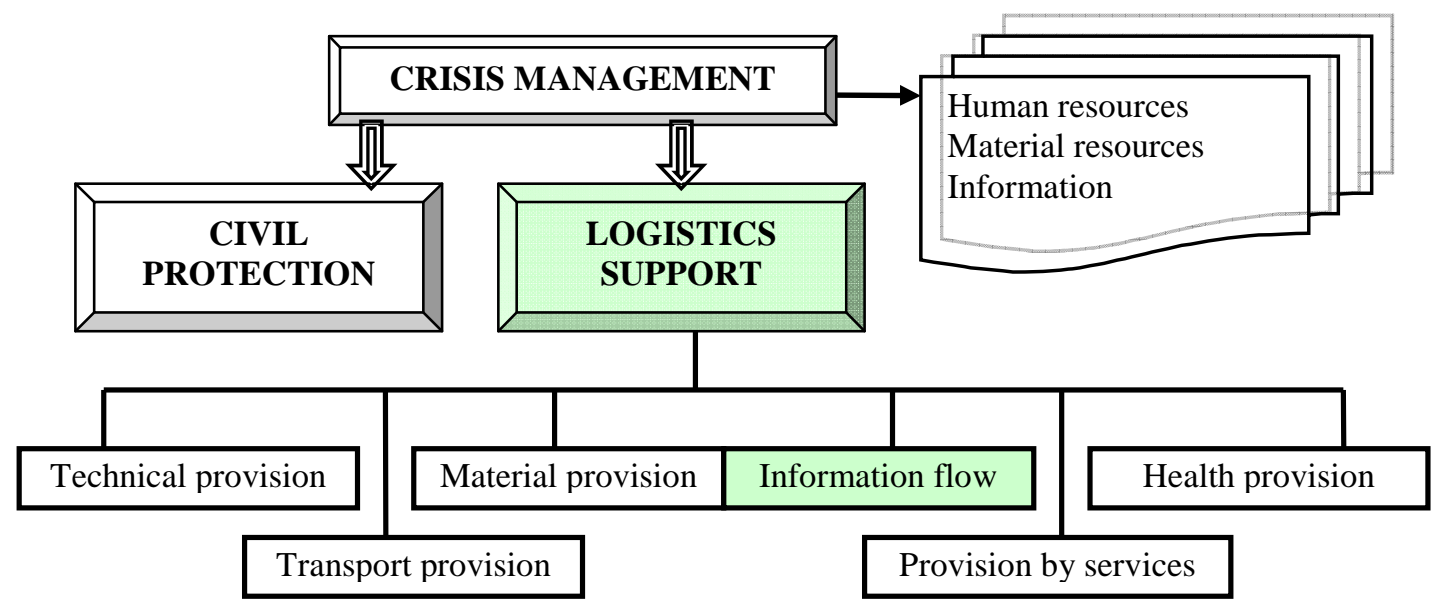

Figure 1: Logistics support in civil protection

Planning process starts with description of authorized group or committee and assignment of a coordinator.

Emergency assistance planning means that planning provides necessary and suitable aid to victims of disaster area. Each kind of emergency situation might have own emergency planning but actually they have lots of common features like:

- Determining of teams and their powers and duties - which one of them will be employed.

- Specifying of command and control centres.

- Determining of sources and opportunities which should be used and setting of systems to reach them.
- Preparing of infrastructure of plans like searching, rescuing, first aid, evacuation, housing, logistic support etc.

- Determining of communication and transportation tools, vehicles.

- Establishing of mechanisms for warning and informing people to be aware.

- Inventorying of sources like human, equipment, material, food, financial source for a province or county in case of emergency.

- Planning of obtaining necessary aid material and equipment in the shortest possible period of time in case of emergency situation.

- Determining of stores, stocking and keeping of materials.

- Searching of ways to send aid material and equipments to far and inaccessible regions.

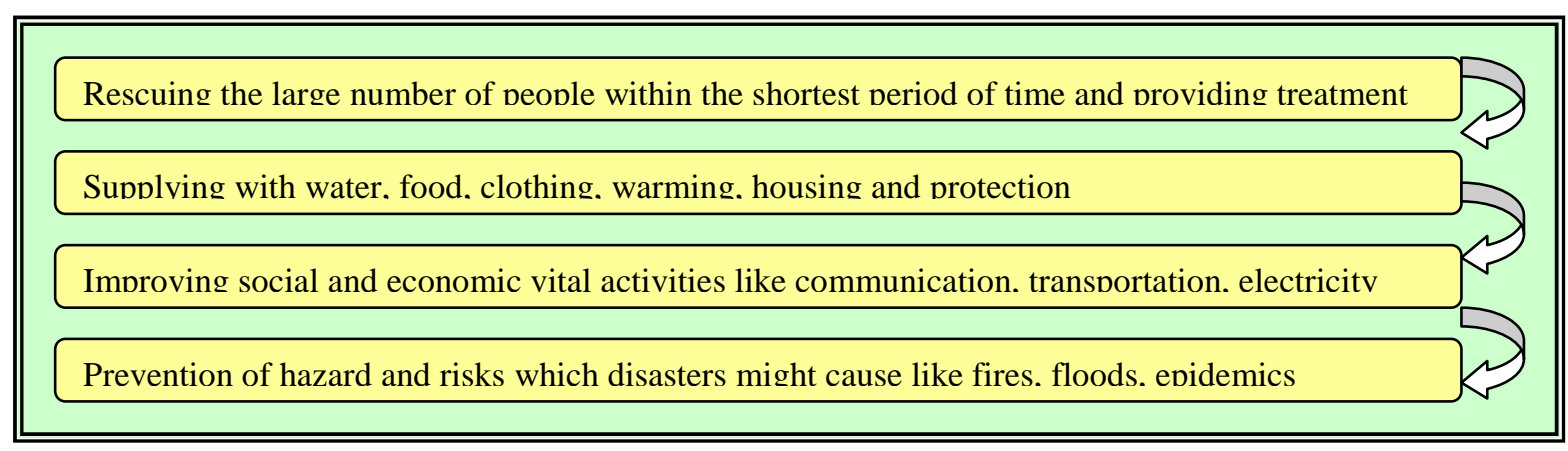

Figure 2: Main purpose of emergency situation planning 
Detailed planning of elements related to places of stores and institution which have sources and stocks, making priorities - which will be used first and transportation of them in case of disaster determining which vehicles they will send and in what number:

- Keeping of emergency aids storage and transportation standards.

- Providing of fund and methods for urgent purchase.

- Activation of regional opportunities in disaster area.

- Planning is provided and implemented with related institutions' participation.
Implementation of civil protection and its logistics provision means to transfer emergency aid goods and emergency aid attendants to disaster areas:

- Transportation from emergency aid stores to disaster areas.

- Creating temporary storage centres in disaster areas.

- Distributing of disaster aids balanced and ordered.

- Processing of stock control and registry mechanism regularly.

- Providing of crisis centre and communication.

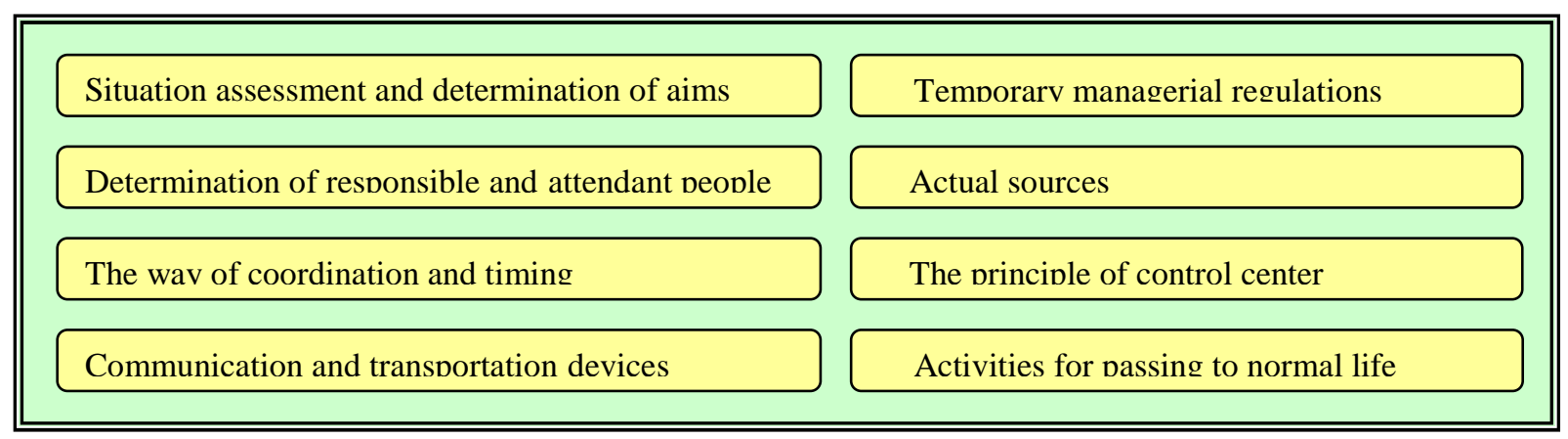

\section{Figure 3: Emergency assistance content}

\section{INFORMATION TECHNOLOGY IN CIVIL PROTECTION}

GSM, GPS, Extranet, GPRS are the sets of technologies that ordinary people have heard about, sometimes not knowing what functions these technologies bring to our day-delays.

Data-GIS is an application for control of fleets in the area of GIS (Geographic Information System) to know the position of vehicles in real time, send and receive messages of equipment, fleet management (Figure 4).

In the operating room, the module allows management through the graphical interface view for the fleet of cars, its position in digital map, its speed, the miles done, and direction of travel. The alarm system allows generating the beginning of the motion of vehicles and issue alerts for SOS. Each car has a box equipped with GPS system, for sending information, which is operated automatically when the ignition of the vehicle.

ICT - Information and Communication Technologies are important tools for the normal performance of any mission. For Events
Management, it is expected that in the future will be intertwined with the Fire Department to update the data.

RIOS program, the interface Surveillance System Alert and Water Resources for ANPC (National Civil Protection Authority) is the application that provides real-time, information hydrometeorological and water quality collected by automatic stations with teletransmission, and some hydrometeorological data.

The following parameters are available to ANPC:

- Hydrometric stations - hydrometric height, tail, quota.

- Water quality stations-temperature, conductivity, oxygen, dissolved, and $\mathrm{PH}$ urbinez.

- Reservoirs-volume, influent flow, off fluent flow.

This application is a fundamental support in the management and planning for possible flooding in the Tagus basin, and beyond.

CDOS (District Operations Command Relief) uses geographic information systems Arcgis (ESRI) for preparation of studies and reports. It is a special information technology for fire departments. 
Also by e-mail came streamline procedures and

Municipal Services of Civil Protection, Civil contacts, and all releases and operational standards, Protection agents and other entities in the system. and weather warnings broadcast in this way by the



Figure 4: Geographic Information System

The administration itself is facilitated with the dematerialisation of individual cases of fire. Generate Application (Human Resource Management), allows in few minutes to know for example, the number of staff by the Active Fire Department, his qualifications etc. Highlight for automatic monthly issue of the Order of Service with a total registration of movements of personnel and other management information bureaucracy.

The Future, guess it is less bureaucratic with the creation and development of the System of National Census and Registration of Fire, "set in the program SIMPLEX 2007, which will through an extranet platform Fire brigades launch and manage the information of new and existing elements fire.

The advantages of this technology has been useful in relief operations in theatres of forest fires, it was possible to locate with any precision the beginning of an outbreak of fire, by examining the concentration of car-fighting that occurred in the first place. In this context it was possible to ascertain, almost in real time, the perimeter of a fire with the observation in digital map of the positioning of the means involved.

As an example of the daily tasks carried out with the use of ICT applications for Events Management, Media Management and Resource Management and Means of Air, they permit monitoring and monitoring of all events through, the registration and classification of these, classification of severity, upgrade of facilities and resources involved in its resolution, registration of all activities and operational decisions and monitoring the activities of air resources.

The main features of these programs are the ability to identify each occurrence in the resources involved and available, its classification and the ability to fight; supply of permanent points of situation, updated and organized, providing information in real-time, based on priorities and response times.

The relationship between logistics and information technology is evident, especially when we talk about solving crises, saving lives. With technology errors become smaller, the response time is getting smaller, and greater efficiency.

\section{CONCLUSION}

Logistics in civil protection means that disasters, people, harm, equipments, saving, solving such technical, information and material process are like a chain with a lot of rings. Each part of this chain is connected strongly to the other and these parts have to be made from right and strong materials. Because, human life depends on this chain. Whenever it is needed, it has to be ready for duty, help, life. Effectiveness, power and speed of Logistics in Civil 
Protection are headstones of this chain and its success depends on them. So, governments, representatives, experts are responsible to ensure the implementation of this circle. Human life is the priceless value and it must not be wasted.

\section{REFERENCES}

Balog, M., Grendel, P., Marasová, D., \& Koribský, I. (2009). Identifikácia a ohodnotenie rizika v tuneli Branisko. Proceedings of the LOGVD 2009 (pp. 2531). FŠI ŽU v Žiline, Slovakia.

Bariak, M., \& Dávid, A. (2007). Informačná bezpečnost'. Dopravné noviny Transport: dvojtýždenník pre dopravu, zasielatel'stvo, logistiku a vel'koobchod, 9(18), p. 49.

Čekerevac, Z. (2009). Internet technologies and Internet business (in Serbian). Kruševac, RS: FIM, ICIM.

Dvořák, Z. (2006). New aspects of transporting dangerous material and oversized shipments. Proceedings of the Transport 2006, XVIth scientific comference (pp. I-39-
I-42). Visše transportno učilišče "Todor Kableškov", Slovakia.

Pecková, L., \& Vidriková, D. (2007). Program management. Proceedings of the Transcom 2007: 7-th European conference of young research and science workers (pp.69-72). University of Žilina, Slovakia.

Soušek, R., \& Dvořák, Z. (2009). Risk identification in critical transport infrastructure in case of central Europe with focus on transport of dangerous shipments. Proceedings of the 13th world multiconference on systemics, cybernetics and informatics WMSCI 2009 (pp. 374-377). International Institute of Informatics and Systemics, Orlando, Florida, USA.

Sventeková, E. (2005). Risk analysis in transport systems, (in Slovak). Proceedings of conference LOGI 2005 (pp. 219-223). University of Pardubice, Pardubice, Czech Republic.

Sventeková, E. (2009). Logistics support of crises situations solving. Mechanics, Transport, Communications, Transport, 3, pp.IV-40 - IV-44 